\title{
Research on Current Situation and Countermeasures of Music Teaching of Non-music Major in Normal Universities
}

\author{
Liu Lei \\ China West Normal University \\ Nanchong, China \\ liulei55668@sina.com
}

\begin{abstract}
Great changes have taken place in people's life with economy development in China. Modern society has higher and higher requirements on people's comprehensive quality, and pays more and more attention to raising art level. The society pays more and more emphasis on music teaching of students not majoring in music with development of quality education in China. All circles of the society have special focus on music teaching condition of non-music major in normal universities due to particularity of normal universities. Therefore, music teaching current situation and countermeasures of non-music major in normal universities are studied in the paper. Significance of normal universities on music teaching of non-music major is described in the paper. Current situation of music teaching in non-music major of normal universities are analyzed, countermeasures to improve music teaching level of non-music major in normal universities are proposed. In the paper, it is believed that emphasis of all departments on music teaching should be improved, music public elective music at different levels should be set, two-way choice between teachers and students should be realized; music curriculum setup should be rationally improved; and music teaching form should be enriched.
\end{abstract}

Keywords-normal universities; non-music major; music teaching; current situation.

\section{INTRODUCTION}

Music can improve people's aesthetic view, cultivate mind, and edify sentiment. It has great role in promoting students' humanities quality, cultural quality and comprehensive quality. Students in normal universities have more and more approach to receive and learn music with development of network information technology and science technology. Students can obtain favorite songs through $\mathrm{TV}$, radio, Internet and other means. They can imitate idols' singing to study music due to prevalence of various talent competition programs. However, students should accept systematic and long-term vocal music training in order to reach certain music level. Therefore, normal universities should implement music teaching on students not majoring in music, thereby meeting demand of students on music.

\section{SignifiCANCE OF NON-Music MAJOR Music TEACHING ON STUDENT QUALITY TRAINING IN NORMAL UNIVERSITIES}

\section{A. Being beneficial for broadening students' knowledge}

Basic knowledge of music should be mastered and utilized for music learning. Students in normal universities should adopt music basic knowledge as foundation in the process of learning music. Creation time and creation background of songs should be comprehended during learning and signing of songs. Therefore, students can comprehend the feelings expressed by the song and background story from the perspective of creation age of the author. Students can comprehend historical knowledge, ethnic customs and cultural knowledge, etc. from the perspective of song, and knowledge of students in normal universities can be broadened.

\section{B. Being beneficial for increasing students' self-confidence}

People have richer and richer leisure entertainment modes with use of science and technology and improvement of people's living standard. In recent years, KTV, Karaoke and similar industries undergo rapid development. Singing with microphone is one of important entertainment modes for people in modern society. Spare time of students in normal universities can't be separated from KTV. However, many students are not confident in themselves, and therefore they only can listen to songs of others in KTV rather than signing by themselves. Or they rarely sing in KTV. This is unconfident performance of students since they believe that they do not learn for singing and can't sing. Students in normal universities have certain understanding on music after professional music learning. Students believe that singing is not difficult through daily music learning, therefore students in normal universities can show by singing, and people good at signing can be even more popular, thereby enhancing students' confidence.

C. Being beneficial for cultivating students' music accomplishment and aesthetic appreciation ability

Music singing is the second-time creation of work. Singers can sing songs according to their own understanding on the 
songs in the process of music singing. Students in normal universities can learn music and music signing is beneficial for cultivating students' art performance ability and music accomplishment. Students can master certain music theory foundation and basic songwriting technique with deepening of normal universities on non-music major teaching. Students can express own emotional world through song creation form.

\section{CuRrent Situation OF NON-Music Major MusiC TEACHING IN NORMAL UNIVERSITIES}

\section{A. Weak continuity of vocal music teaching}

Normal universities mainly adopt the form of pubic elective course for music teaching of students not majoring in music. Public elective course is implemented aiming at universities as a whole. Students of selective courses are more generally. However, vocal music teaching has certain particularity. Since voice of each student is different with own different characteristics. Different students have different problems on singing of the same song. It is required that students can provide one-to-one guidance and exchange on students, thereby actually promoting music level of students. In addition, students only can select public selective course once within one semester in normal universities. However, music selective course is one of very popular selective course with more students. Many students have no chance to select music. In addition, some normal universities regulates that students should not repeatedly select public selective course in the same category. Students only can select one vocal music course. However, class hours of each semester are less, teaching continuity of normal universities on non-music major students is weak. It is difficult for students to learn more music knowledge, which can't meet students' actual demand on music.

\section{B. Insufficient attention to music teaching, and lack of infrastructure}

A lot of normal universities do not stress music teaching of non-music major. It is believed that music is only a selective course. Sufficient attention is not paid to music curriculum setup. In the paper, music teaching condition of non-music major in normal universities is investigated. Fig. 1 shows that normal universities pay great attention to music teaching of non-music major. It is obvious in the paper that only $4.5 \%$ universities pay much attention to music teaching of nonmusic major, and $21.1 \%$ universities pay more attention to music teaching of non-music major, $46.7 \%$ universities pay general attention to music teaching of non-music major, and $27.7 \%$ pay less attention to music teaching of non-music major. Therefore, normal universities do not pay much attention to music teaching of non-music major. Normal universities are lack of music teaching facilities of non-music major, and provide simpler teaching equipment, which mainly rely on stimulating auditory and visual perception of students. Most music teaching still stays in the level of theory teaching. Therefore, music teaching is limited greatly. Teaching process is more boring and monotonous. Students' music appreciation level can't be improved easily. Some students even do not have much understanding on the most basic stave in music.
Since normal universities do not attach enough importance to the music teaching, and are lack of teaching infrastructure, it is difficult to implement music teaching. Students not majoring in music have lower interests in music course. Keys can't be mastered in music appreciation. Normal universities can't reach purpose for music teaching of non-music major.

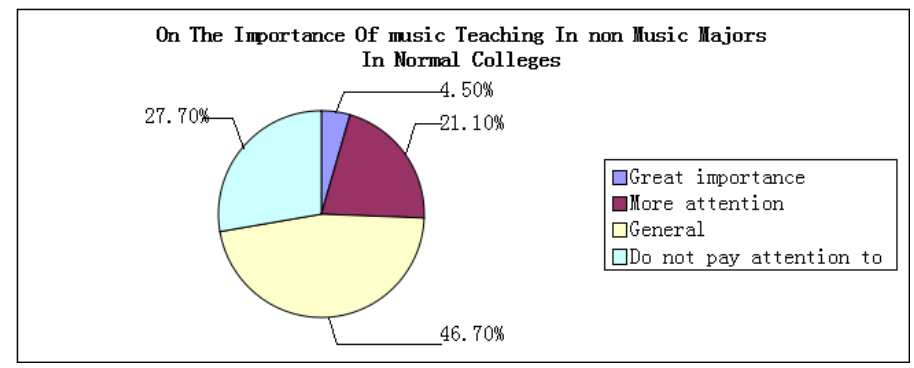

Fig. 1.Emphasis of normal universities on music teaching of non-music major

\section{Boring music teaching content and single teaching form}

Many majors of normal universities are greatly updated in teaching content and teaching thought with acceleration of diversification process in education development. Traditional teaching development mode is still utilized for music teaching mode. Music teaching of non-music major in normal universities can't be greatly improved. In addition, non-music teaching materials are not updated in normal universities. Teaching contents are boring. Students not majoring in music can't timely comprehend modern music learning mode. Music basic skills of students not majoring in music and music basic knowledge can't be improved. In music teaching, basic knowledge of music theory includes the follows: time signature, beat, tempo, rhythm and other commonly used symbols. Basic musical instruments, related music appreciation knowledge, etc. are not well comprehended. Fig. 2 shows music teaching mode condition of non-music major in normal universities followed by discussion method, questioning method, explanation demonstration method and exercise guidance method. It is known that normal universities have single music teaching modes on students not majoring in music, namely traditional teaching method. Students' participation enthusiasm is low. Since teaching contents in normal universities are boring with single teaching mode, therefore, normal universities implement drab music teaching on students not majoring in music. Students not majoring in major will lose interests on music learning over time.

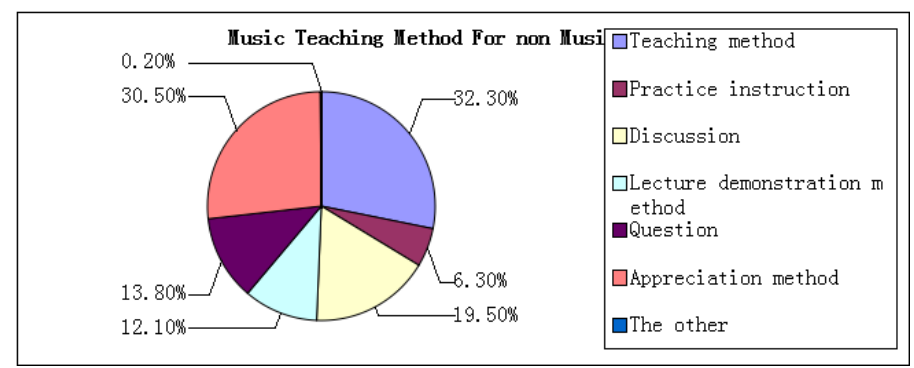

Fig. 2.Music teaching mode of non-music major in normal universities 


\section{Music TEACHING COUNTERMEASURES OF NON-MusiC MAJOR IN NORMAL UNIVERSITIES}

\section{A. Improving attention of all departments to music teaching}

Normal universities should pay much attention to music teaching of students not majoring in music. Therefore, music teaching quality of non-music major can be effectively improved. Firstly, educational administration department of normal universities should supervise and manage music teaching course of non-music major, thereby promoting regular implementation of music teaching work of non-music major. In addition, educational administration department of normal universities should disclose music teaching purpose, teaching requirements, teaching contents, teacher and student attendance system and evaluation mode of non-music major in university websites. Music course selection of students not majoring in music is guided. Implementation condition of music course is strictly supervised, such as regular and irregular surprise inspection of student attendance cleaning and teachers' teaching effect, etc. Assessment efforts of practice course should be increased in music learning appraisal of students not majoring in music, thereby reducing theory exam and cracking down fraud behaviors in the exam. Meetings can be held for adjusting and standardizing attitudes of teachers and students. The measures can effectively guarantee teaching quality of teachers, emphasis of students on vocal music course, and it is also beneficial for students to improve vocal music theory knowledge and singing skills.

\section{B. Offering public elective music at different levels, and realizing two-way choice between teachers and students}

Since music public elective courses are not highly correlated in normal universities, new students are repeatedly involved in music selective course of normal universities. Music professional knowledge learning of students can't play any role. The enthusiasm of teachers is reduced. Normal universities can consider offering vocal music basic knowledge elective course at the first year in the aspect of music learning of non-music major in order to improve the situation, and the students should be controlled within 50-100. Main content of teaching includes basic music theory knowledge and vocal music introduction knowledge. Teachers can gradually comprehend each student during class. Students also can comprehend knowledge points and class form of vocal music class through ten class times. Students and teachers can select in two ways according to satisfaction on opponent party at the end of semester, thereby entering vocal music improvement class of next semester. Students of vocal music improvement class can be greatly reduced in the second semester in order to improve teaching effect and guarantee effective learning time of each student.

\section{Rationally improving music curriculum setup}

Most students of normal universities not majoring in music select music course due to favor on signing. Currently, various normal university colleges mainly adopt the form of music appreciation on music public selective course. Rare normal universities set up music public selective course and practice selective course according to student actual demand and teachers' teaching plan, such as learning guitar, piano and other instruments, etc. Students' learning initiative and enthusiasm can be improved. Music teaching only refers to teaching music knowledge on platform. Many students will lose interests. Therefore, normal universities should pay more attention to considering students' learning interest during setup of music teaching course of non-music major. Students not majoring in music are more interested in skill music course with strong maneuverability according to music teaching experience. Students can be grouped into small bands, which not only can improve students' interest in learning, but also can exercise mutual cooperation spirit of students in the aspect of instrumental music. Chorus can also be used as object considered by music elective course in terms of vocal music since students not only should make effort to sing own voice well, but also should cooperate with other voices more importantly in chorus class. It plays an active role in cultivating team coordination spirit of students.

\section{Enriching music course teaching form}

Music teaching form should be enriched for music teaching of students not majoring in music of normal universities. Music beauty can be experienced and appreciated through music appreciation teaching and other auxiliary means. Rich and colorful teaching form can be utilized for stimulating students' learning interests in music appreciation class. Normal universities can utilize multimedia courseware, physical display and instrument playing form. For example, I allow students to recognize and contact physical instrument- Erhu, experience playing mode of Erhu and comprehend timbre of Erhu in the teaching activity of music appreciation course Erhu solo 'Horse Racing', thereby causing students' interests of appreciation. Game form is utilized. Music game is pleasure and interactive, and it is teaching mode favored by Erhu. Performance form can include accompaniment performance, dance performance, singing performance, role playing, teachers can choose according to the content of music appreciation. When students are organized for music performance, student's strong participation awareness and creation enthusiasm are mainly mobilized, for example: children can use different instruments in 'Watch Shop': angle iron, small bell and sand ball can be used for respectively producing rhythms to show happy scene of large clock, small bell and stopwatch at watch shop for performing concerts.

\section{CONCLUSION}

Currently, quality education is flourished, and music teaching is not limited to listening to music and relaxing body and mind but appreciating music works and feeling music beauty. Resonance of music works and student inner emotion can be reached through vivid thinking mode, thereby improving students' aesthetic taste and music quality. Student culture of normal universities is higher with rich emotional world. It is very important to implement music teaching on students not majoring in music. In the paper, significance of normal universities on music teaching of non-music major is described. Current situation of music teaching of non-music major at normal universities is analyzed. Countermeasures to improve music teaching level of non-music major at normal 
universities are proposed. In the paper, it is believed that emphasis of all departments on music teaching should be improved. Music public selective courses at different levels are set up. Two-way choice between teachers and students can be realized. Music curriculum setup is rationally improved. Music course teaching form can be enriched.

\section{REFERENCES}

[1] Dong Xiufang. "Vocal music teaching of non-music major at higher vocational colleges-with vocal music public elective course of Jiangsu Food and Pharmaceutical Science College," Music Time and Space. 2014, vol. 24 , pp. 24-26. (In Chinese)

[2] Wang Jingyi. "Research on public selective course teaching mode of non-music major at higher vocational college," Journal of Nanchang Education College, 2013, vol. 1, pp. 72-73. (In Chinese)

[3] Yang Liu. "Analysis on approach for cultivating vocal music accomplishment of talents not majoring in music," Journal of Guangxi Science and Technology Normal University. 2014, vol. 1, pp. 123-124.
[4] Wang Nan. "Necessity and feasibility of building music major in colleges not majoring in music," Not Only Music. 2012, vol. 7, pp. 7173. (In Chinese)

[5] Qiao Kuankuan. Song Zheng. "Music education current situation investigation and countermeasure research of undergraduates not majoring in music-with South China Agricultural University as example," Journal of Shaoguan University. 2012, vol. 1, pp. 88-90. (In Chinese)

[6] Shi Xiayang. "Absence and countermeasures of music education of universities not majoring in music," Journal of Chongqing Institute of Science and Technology (Social Science Edition). 2012, vol. 17, pp. 7981. (In Chinese)

[7] Wang Shihao. "Necessity of setting up chorus course for non-music major at colleges and universities," Art Education. 2014, vol. 1, pp. 24 27. (In Chinese)

[8] Zhu Yitong. "Exploration of music education of undergraduates not majoring in music," Art Appreciation. 2015, vol. 9, pp. 14-17. (In Chinese)

[9] Shi Baoyan. "Realization of music education objective of undergraduates not majoring in music," Not Only Music. 2013, vol. 8, pp. 79-81. (In Chinese) 